\title{
Measuring the Tax Incidence of Social Security Taxes in China: Evidence from a Quasi-Natural Experiment of Tax Collection Entity Shift
}

\author{
Fei Han \\ School of Public Finance and Taxation, Central University of Finance and Economics, Beijing, China \\ Email address: \\ aotian87@live.cn \\ To cite this article: \\ Fei Han. Measuring the Tax Incidence of Social Security Taxes in China: Evidence from a Quasi-Natural Experiment of Tax Collection \\ Entity Shift. International Journal of Economic Behavior and Organization. Vol. 8, No. 4, 2020, pp. 101-106. \\ doi: $10.11648 /$ j.ijebo.20200804.13
}

Received: December 23, 2020; Accepted: January 5, 2021; Published: January 12, 2021

\begin{abstract}
Measuring the tax incidence is a classical yet on-going debate in public economics and public finance. It is also an important issue for policymaking because it provides information of the impact of labour costs on firm decisions. However, the incidence varies across different environments, but the existing literature mostly draws on the experience of developed countries, leaving the developing countries under-investigated. To fill the gap in the literature, this study focuses on China's case. Its significance derives from the fact that China's rapid-growing economy relies on its massive population and labour migration while its firms are sensitive to its high social security tax rates. Moreover, the identification of the underlying causality can be failed due to selection bias and simultaneity. Thus, this study exploits a quasi-natural experiment of social security tax collection entity shift to unravel the underlying causal link from social security tax burden to the employment and wages. Drawing a large sample of firm-level data of the above-scale firms in the manufacturing sector of China, this study takes an instrumental variable approach and finds out that the social security taxes significantly suppresses wages by 3.08 percent. Whereas lowered wages increase the employment in turn by 5.26 percent, also suggesting that the tax burden is shared by both the employer and the employee. As for heterogeneities, the empirical evidence of this study shows that the cost effect of social security is more significant in China's coastal regions where the manufacturing agglomeration is higher, in large-scale firms that have annual income more than 50 million yuan per year, and in non-state-owned firms.
\end{abstract}

Keywords: Tax Incidence, Social Security Tax, Collection Entity Shift

\section{Introduction}

Social security tax incidence on firms is a classical yet on-going debate in public economics. Advancing understanding in such an issue lends additional and important insight into how tax policies affect firms' behaviours. However, most existing empirical studies draw on the experience of developed countries, leaving developing countries under-investigated, despite the fact that developing countries, which rely on labor intensive production, are playing an increasingly important role in the global supply chain. To fill the gap in the literature, this study turns to China's manufacturing sector and aims to shed fresh light on how social security tax affects firms' wages and employment. China provides an interesting case for such an inquiry because: 1) its every-growing economy is pillared by its massive labour force, distortive effects of social security taxes can have huge and widespread impacts on the economy; 2) although China's personal income tax is minor, its social security tax rate is of the highest in the world, which causes heavy burden on firms' business; 3) The Chinese social security administration is decentralized and province-based, each province has the discretion to adjust the collection entity or the enforcement intensity, which provides necessary variation for policy evaluation.

In the past two decades, China's social security system has been thoroughly reformed from a planned-economy legacy to a gradually modernized pay-as-you-go system. During this process, hundreds of central and local policies have been enacted, which calls for more policy evaluation that has been 
relatively neglected in this field. China's social security tax includes 5 kinds of fees: pension, medical insurance, maternity, unemployment, and employment injury. The collection and payment of these fees are fully operated within local governments' discretion. What is more, different provinces even assign different collection entities. 19 provinces choose the local tax bureau, while the rest take the local social security and human resource administration, which in fact generates certain a dual-track system. These two collection entities differ in their collecting capacity. The tax bureau is better-equipped and -informed in collecting taxes and fees from firms. Due to widespread evasion and avoidance, some provinces switched to the tax bureau for collection efficiency. Meanwhile, some provinces may stick to the human resource administration because of local politics (Liu 2011) [1]. Thus, the difference in collection entity generates the variation in enforcement intensity that is independent of labour demand and supply across time and space and provides an opportunity to locally identify the underlying causal impacts.

Accordingly, this paper exploits the difference in collection entity as the proxy variable for the unobserved enforcement intensity and the instrument variable (IV) for the effective social security tax rate of firms. Drawing on China's above-scale manufacturing firms' annual survey, this study finds that wages in the provinces using the local tax bureau are significantly lower by 3.08 percent. Meanwhile, employments in these provinces are significantly higher by 5.26 percent, suggesting that higher social security tax rate, caused by more intensive enforcement, causes certain cost-effect that lowers wages but promoting the employment. This can be the consequence of the fact that to some extent the labour may prefer long-term welfare to short-term wages. In further heterogeneity examination, this paper discovers the cost-effect of social security taxes has more significant distortive impacts in the populous coastal areas, non-state-owned firms, and large-scale firms that have an annual revenue more than 500-million yuan.

This study has several contributions. First, it provides evidence that collection institutional choices can affect the tax incidence. It was commonly believed that the tax incidence is independent of actual statutory details and collection institutions, and the tax burden of labour taxes must be shared by the employer and the employee. Under this circumstance, the underlying the tax incidence is only determined by the shape of curves of labour demand and supply (Rosen and Gayer 2021) [2]. Moreover, macro-level evidence seems support this neo-classical conclusion. That the proportion of labour output in the national economy has been rather steady in the past decades in developed countries while revenues of social security taxes have been continuously increasing implies the social security tax burden are shared by employers (Saez Schoefer, Seim 2017) [3]. However, Saez, Matsaganis and Tsakloglou (2012) [4] employ a regression discontinuity design and discover that social security reform in Greek makes the firm bear the tax burden solely while the labour supply and income remain unchanged.

Second, it adds to the debate of labour-related taxes with evidence from China. Gruber (1997) [5] and Anderson and Meyer (1997; 2000) [6-7] find that employers are able to shift the payroll tax burden to employees in the US. Besley and Case (2000) [8] document that America's injury tax has no significant impacts on wages and employment. On the contrary, Kugler and Kugler (2009) [9], Kugler, Kugler and Prada (2017) [10] discover that Columbian firms can only pass one fourth to one third of the payroll tax burden to the employee. This study instead finds that the Chinese firm lower the wage while increasing employment scale in front of higher social security tax rates.

Third, this study contributes to the literature on China's social security taxes. Nielson and Smyth (2008) [11] and Li and Wang (2011) [12] both find that higher social security taxes can suppress wages. However, these studies do not investigate the distortive effects on employment. This study, on the one hand, echoes their findings with similar empirical evidence on wage while, on the other hand, provides fresh evidence that such a wage reduction can lead to employment increase.

To examine the causal impact of China's social security taxes on employment and wages at the firm-level, the rest of this study is organized as follow: the second part discusses data, variables, and the empirical strategy; the third part implements OLS and IV regression; the fourth part investigates the heterogeneity; the final part concludes.

\section{Data, Variable and Empirical Strategy}

\subsection{Data and Variables}

This study exploits the annual survey of China's above-scale manufacturing firms. This data can be representative considering that China, as a developing country, also suffers from informality, thus only its above-scale enterprises have better accounting records and accountability. Data of the paid social security taxes are only available in years from 2004 to 2007. This study excludes Tibet, Hongkong, Macau, and Taiwan due to their exceptive fiscal arrangement.

In line with Nie et al (2012) [13], I exclude the observations with abnormal data values in several important variables. First, observations are removed when the number of employees is less than 30 or the total asset value is less than 10 million yuan, because these two values are indicators of the "scale" thresholds and only those firms with more employees and assets should be defined as "above-scale". Second, observations with unreasonable accounting records are excluded, including more liquid asset than total asset, more fixed-asset than total asset, more annual depreciation than accumulated depreciation, negative assets, negative business revenues, more value-added tax than annual added value. Third, since this study focuses on tax incidence on labour demand, I delete the observations with negative wages, missing wages, and missing social security taxes. Furthermore, the data is trimmed at the $99^{\text {th }}$ percentile of the annual effective social security tax rate on both ends. Last, given than the newly established firms may enjoy tax preferential 
treatments, this study excludes firms established in the less than 4 years. About 450 thousand firms are left for the regressions, about 110 thousand per year.

The core explanatory variable of this study is the social security tax rate, which is measured by the ratio of firms' social security tax payment on annual total wages. Notably, the social security tax payment includes two variables in this dataset: 1) pension and medical insurance; 2) maternity, injury, and unemployment insurance. However, the latter variable has more missing values. Thus, this study uses the "pension and medical insurance" as the proxy for total social security tax payment. This may not lose representativeness because the rate of pension and medical insurance fees combined is about
$36 \%$ while the rate of the minor three combines is only about $4 \%$. The core dependent variables are the average wage and employment of each firm.

Control variables include: 1) the total asset of the firm to control for the variation in the firm scale; 2) average profit and concentration ratio (HHI) of each industry are controlled for industry-specific time-variant difference; 3) the tightness of the local labour market (the number of the unemployed/the number of job posts) is employed to absorb differences in the local labour market; 4) GDP per capita of each province is added for time-variant changes in the local economic developmental variables. The statistical descriptions of these variables are displayed in the following table 1 .

Table 1. Statistic Descriptive.

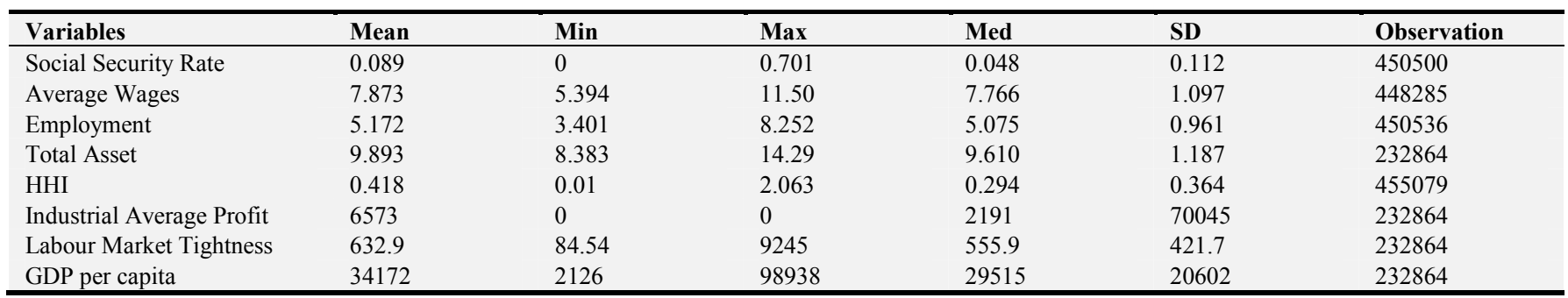

\subsection{Empirical Strategy}

Both selection bias and simultaneity can lead the identification to failure. On the one hand, firms that rely on labour incentives tend to pay more welfares for the employees, which causes selection bias. On the other hand, social security taxes affect the labour cost which is the key part of labour demand and supply, thus, the simultaneity between demand and supply also results in un-identification of the underlying causal link from social security tax to wages and employment. Consequently, the average treatment effect cannot be identified, and an alternative empirical strategy should be considered. Since difference collection entity only affects the difference in enforcement capacity and efficiency which only interfere with the effective social security rate but does not influence other labour demand choices, this study argues the difference in social security collection entity can be used as the proxy variable for the unobserved enforcement and the instrumental variable of the effective social security tax rates.

With the perspective of policymaking, the exclusiveness of this IV can be satisfied because: 1) changing collection entity does not aim at affecting local labour market; 2) Liu (2011) [14], through the lens of political resource scrambling, documents that local political factors play a determinant role in choosing the collection body; 3 ) the collected revenue is used for maintaining the well-being of the retiree who have already left the labour market. With the perspective of firms' choices, this instrumental variable is also feasible since firms cannot participate in such a policymaking process in the single-party authoritarian regime of China. However, during the sample period, no province changed the collection body. Thus, such an IV can only reflect the variation across space.

During 2004 and 2007, 17 provinces used the tax bureau.
This study uses a dummy variable as the indicator -1 for the tax bureau, 0 for otherwise. Furthermore, compared with previous studies that used the average local tax rate as the instrumental variable (Anderson and Meyer 1997) [15], this IV is less affect by the auto-correlative issue and in fact belongs to the Wald estimation (Angrist and Pischke, 2009) [16].

\section{Regressions and Results}

\subsection{OLS Regressions}

As a reference, this section starts with OLS regression of the following model $1 . \operatorname{sir}_{i, t}$ is the effective social security tax rate; $\beta_{1}$ is the co-efficient of interest; $X_{i, t}$ (vector) represents the above-mentioned covariates; $t$ is the year fixed effect; $\xi_{i, t}$ denotes the residual. Regressions use heteroscedasticity-robust standard error. As a test of sensitivity and robustness, this study employs both fixed-effect and random-effect models in table.

$$
\text { employ }_{i, t} \text { or } \text { wage }_{i, t}=\alpha_{1}+\beta_{1} \operatorname{sir}_{i, t}+\delta X_{i, t}+t+\xi_{i, t}
$$

As displayed in the column 1 and 2 of table 2, increases in social security tax rate have significant negative impacts on wages. Wages increase by 0.6 to 0.74 percent on each percentage point social security tax rate reduction. Meanwhile, social security tax burden also has significant negative impacts on employment. However, the suppressing effect on employment is much lower than that on wages $(-0.158)$. The estimated coefficient does not differ much between fixed-effect and random-effect models. Moreover, the R-squares of the employment regressions are below 0.1. Table 2 shows that social security tax can distort both employment and wages in China's manufacturing sector. Since wages are decreased more significantly than the employment, it is indicated that 
employees bear the majority of social security tax burden.

Table 2. OLS Regressions.

\begin{tabular}{|c|c|c|c|c|}
\hline \multirow{3}{*}{ Variables } & (1) & (2) & (3) & (4) \\
\hline & FE & $\mathbf{R E}$ & FE & $\mathbf{R E}$ \\
\hline & Wage & Wage & Employment & Employment \\
\hline Social Security Tax Rate & $\begin{array}{l}-0.738^{* * *} \\
(0.012)\end{array}$ & $\begin{array}{l}-0.595^{* * *} \\
(0.010)\end{array}$ & $\begin{array}{l}-0.158^{* * * *} \\
(0.009)\end{array}$ & $\begin{array}{l}-0.158 * * * \\
(0.008)\end{array}$ \\
\hline Controls & Yes & Yes & Yes & Yes \\
\hline Constant & $\begin{array}{l}5.274 * * * \\
(0.421)\end{array}$ & $\begin{array}{l}0.830 \\
(0.541)\end{array}$ & $\begin{array}{l}2.67 * * * \\
(0.314)\end{array}$ & $\begin{array}{l}-1.07 * * * \\
(0.412)\end{array}$ \\
\hline Observations & 348,978 & 348,978 & 350,424 & 350,424 \\
\hline R-square & 0.235 & 0.221 & 0.062 & 0.043 \\
\hline
\end{tabular}

Notes: standard errors in parentheses; $* * *, * *$, and $*$ denote statistical significance at the $1 \%, 5 \%$, and $10 \%$ levels, respectively.

\subsection{Regressions}

However, OLS regressions cannot reveal the underlying causality from tax burden to labour demand distortion due to selection bias and simultaneity. Thus, this study takes the IV approach proposed in the previous section - taking the collection entity (dummy) as the IV to identify the local average treatment effect (LATE). This IV only affects the collection interaction between the collection entity and the firm while remains independent of labour supply and demand between the firm and the labour. This subsection uses two-stage-least-square model in model 2 and 3. $D_{p, t}$ is the dummy variable of collection entity, 1 assigned to provinces using the tax bureau, and 0 for the human resource administration. $s_{p}$ is the firm fixed-effect model. IV regressions also employ heteroscedasticity-robust standard error.

$$
\begin{gathered}
\operatorname{sir}_{i, t}=\alpha+\gamma D_{p, t}+\delta X_{i, t}+t+s_{p}+\xi_{i, t} \\
\text { employ }_{i, t} \text { or }_{\text {wage }}=\alpha^{\prime}+\omega \operatorname{sir}_{i, t}+\delta^{\prime} X_{m, t}+t+s_{p}+\xi_{i, t}
\end{gathered}
$$

Table 3. IV Regressions.

\begin{tabular}{llll}
\hline \multirow{2}{*}{ Variables } & $\mathbf{( 1 )}$ & $\mathbf{( 2 )}$ & $\mathbf{( 3 )}$ \\
\cline { 2 - 4 } & First Stage & Second Stage & Second Stage \\
\cline { 2 - 4 } & Social Security Tax Rate & Wage & Employment \\
\hline Social Security Tax Rate & & $-3.078^{* * *}$ & $5.263^{* * *}$ \\
Collection Entity (Dummy) & $0.011^{* * *}$ & $(0.299)$ & $(0.263)$ \\
& $(0.0003)$ & & \\
Controls & Yes & Yes & Yes \\
Constant & $-0.084^{* * *}$ & $-0.421^{* * *}$ & $-0.613^{* * *}$ \\
& $(0.002)$ & $(0.041)$ & $(0.039)$ \\
Observations & 350,942 & 350,886 & 350,942 \\
Weak IV Wald Test (F stats) & 1236.25 & & \\
\hline
\end{tabular}

Notes: standard errors in parentheses; $* * *, * *$, and $*$ denote statistical significance at the $1 \%, 5 \%$, and $10 \%$ levels, respectively.

As demonstrated in the column1 of table 3, the collection entity dummy variable has significant positive impacts on firms' social security tax rates, which further proves that the IV is relevant for the causal inference. This verifies the facts that the tax bureau is better equipped and experienced in collecting taxes and fees from firms and has higher collecting efficiency. The F statistics of the weak IV Wald Test far exceeds the rule-of-thumb threshold of 10 , showing that the IV identification is not weak in this sample.

Column 2 and 3 report the second-stage results. In column 2, increases in the social security tax rate can significantly lower wages by 3.08 percent. The magnitude of the estimated coefficient is larger than column 1 and 2 of table 2, which suggests that the IV regression also mitigates the measurement error in the sample. However, the column3 shows that higher social security tax rate can significantly increase the employment by 5.26 percent. This result seems counter-intuitive, especially regarding the neo-classical prediction that higher labour cost should lower the employment. This study argues that this result is in fact more plausible for social security tax. Because, unlike personal income tax, social security tax has positive utility owing to the underlying welfare gain (Anderson and Meyer 1997) [17]. Consequently, labour can accept certain substitution between wage and social security contribution (Summers 1989) [18]. Under this circumstance, social security tax rate can both lower wages and increase the employment. Moreover, the results in column 2 and 3 of table 3 are more reasonable in terms of labour demand elasticity which should be negative. Whereas the results in table 2 may imply that the labour demand elasticity is positive - labour is a scarce resource, which seems contradictory to China's case.

\section{Heterogeneity}

This section further investigates the heterogeneity. To start with, this section examines the heterogeneity among different firm ownerships. As a legacy of the planned economy and socialism-based politics, policy preferences and technological 
bases vary among different ownerships. State-owned firms usually have larger scales but more administrative and budget constraints; foreign firms tend to have better technologies; while the domestic private firms are more efficient but enjoy less policy preferences. Using the IV estimator of the last section, table 4 reports the differentiated impacts of social security tax on wages and employment for each ownership.

As shown in the column 1 and 4 of table 4 , wages of state-owned firms are not significantly affected by social security tax burden while the employment is significantly suppressed, in both statistical and economical terms. This can be the consequence of the fact that the Chinese state-owned firms face certain wage rigidity, and the tax burden is fully embodied in employment reduction. Meanwhile, column 2 and 5 show that social security tax has negative impact on foreign firms' wages (-3.73 percent) and positive impact on employment (7.56 percent), which are in line with the pattern of table 3. Similarly, column 3 and 6 demonstrate that the social security tax lowers wages (8.92 percent) and increases the employment (6.59 percent) of the private firms. However, the distortion in wages is more significant for the private firm than for the foreign firm. This is because the private firms in China are usually smaller than the other two kinds, wage reduction can further reduce its bargaining power in the labour market.

Table 4. Heterogeneity across Firm Ownership.

\begin{tabular}{|c|c|c|c|c|c|c|}
\hline \multirow{3}{*}{ Variables } & (1) & (2) & (3) & (4) & (5) & (6) \\
\hline & State & Foreign & Private & State & Foreign & Private \\
\hline & Wage & Wage & Wage & Employment & Employment & Employment \\
\hline Social Security Tax Rate & $\begin{array}{l}0.487 \\
(1.251)\end{array}$ & $\begin{array}{l}-3.734 * * * \\
(1.105)\end{array}$ & $\begin{array}{l}-8.919 * * * \\
(1.291)\end{array}$ & $\begin{array}{l}-20.419 * * * \\
(4.562)\end{array}$ & $\begin{array}{l}7.559 * * * \\
(1.575)\end{array}$ & $\begin{array}{l}6.591 * * * \\
(0.977)\end{array}$ \\
\hline Controls & Yes & Yes & Yes & Yes & Yes & Yes \\
\hline Observations & 106,025 & 104,238 & 138,713 & 106,458 & 104,555 & 139,411 \\
\hline
\end{tabular}

Notes: standard errors in parentheses; $* * *, * *$, and * denote statistical significance at the $1 \%, 5 \%$, and $10 \%$ levels, respectively.

Next, this study investigates the heterogeneity across regions. Based on developmental level and climate, geographical resemblance, this part divide China into four parts - east, northeast, middle, and west. The east is the most developed and populous region, while the west is the least. The northeast used to be the industrial base but suffers from population loss in recent decades. As displayed in table 5, social security tax has significant impacts on wages and employment on in the coastal east. In the eastern China, 1 percentage point rise in social security tax could significantly lower 3.8 percent wages but generate 8.5 percent employment. This pair of result suggests that table 3's results mainly derive from the east region which has the most observation in the sample. In other regions, social security tax only suppresses wages, showing that the tax burden is mainly borne by the employee.

Table 5. Heterogeneity across Regions.

\begin{tabular}{|c|c|c|c|c|c|c|c|c|}
\hline & (1) & (2) & (3) & (4) & (5) & (6) & (7) & (8) \\
\hline \multirow[t]{2}{*}{ Variables } & East & North-East & Middle & West & East & North-East & Middle & West \\
\hline & Wage & Wage & Wage & Wage & Employment & Employment & Employment & Employment \\
\hline Social Security Tax Rate & $\begin{array}{l}-3.816^{* * *} \\
(0.902)\end{array}$ & $\begin{array}{l}-15.655^{*} \\
(41.134)\end{array}$ & $\begin{array}{l}-3.432 * \\
(0.346)\end{array}$ & $\begin{array}{l}-6.695^{*} \\
(12.505)\end{array}$ & $\begin{array}{l}8.507 * * * \\
(2.343)\end{array}$ & $\begin{array}{l}-13.319 \\
(36.651)\end{array}$ & $\begin{array}{l}1.680 \\
(0.305)\end{array}$ & $\begin{array}{l}-20.638 \\
(9.917)\end{array}$ \\
\hline Controls & Yes & Yes & Yes & Yes & Yes & Yes & Yes & Yes \\
\hline Observations & 248,743 & 24,562 & 32,093 & 43,578 & 249,709 & 24,778 & 32,208 & 43,729 \\
\hline
\end{tabular}

Notes: standard errors in parentheses; $* * *, * *$, and $*$ denote statistical significance at the $1 \%, 5 \%$, and $10 \%$ levels, respectively.

Finally, this section investigates the heterogeneity across firm scales. Firms in the sample are categorized into 5 categories based on their business revenue levels -- annual business revenues between 1 to 5 million yuan, 5 to 10 million, 10 to 50 million, 50 to 100 million, and more than 100 million. As demonstrated by colum 4 and 5 of table 6 , firms with revenues more than 50 million are significantly affected by social security tax, especially the firm has a revenue between 50 million and 100 million. This can be the consequence of the fact that larger firms have more employees and are sensitive to labour cost.

Table 6. Heterogeneity across Firm Revenue Scale.

\begin{tabular}{|c|c|c|c|c|c|}
\hline & (1) & (2) & (3) & (4) & (5) \\
\hline \multirow[t]{2}{*}{ VARIABLES } & $1 \mathrm{M}$ & $5 M$ & $10 M$ & $50 M$ & $100 \mathrm{M}$ \\
\hline & Employment & Employment & Employment & Employment & Employment \\
\hline \multirow[t]{3}{*}{ Social Security Tax Rate } & 11.509 & 38.317 & 56.107 & $10.276^{* * *}$ & $5.619 * * *$ \\
\hline & (29.118) & (34.984) & $(4,863.220)$ & $(3.342)$ & $(1.390)$ \\
\hline & Wage & Wage & Wage & Wage & Wage \\
\hline \multirow[t]{2}{*}{ Social Security Tax Rate } & -2.782 & 14.364 & -39.398 & $-12.087 * * *$ & $-10.331 * * *$ \\
\hline & (5.454) & (9.499) & (108.201) & $(3.695)$ & $(1.856)$ \\
\hline Observations & 2,079 & 23,235 & 174,659 & 69,814 & 76,649 \\
\hline
\end{tabular}

Notes: standard errors in parentheses; $* * *, * *$, and $*$ denote statistical significance at the $1 \%, 5 \%$, and $10 \%$ levels, respectively. 


\section{Conclusions}

Taking the difference between fiscal regimes for social security collection as the IV, this study finds that social security tax burden can significantly lower wages but increases the employment. Since the employment effect is larger than the wage reduction, firms bear more tax burden by 2 percent than the employee. Furthermore, such effects are more significant in the coastal areas, non-state-owned firms, and large-scale firms. Based on the empirical findings of this paper, tax collection does affect the tax incidence, which suggests that tax incidence is a rather local and temporal issue. Furthermore, populated areas and firms of better technology and performance may have bigger bargaining power, which can be the driving factor of the incurred wage reduction and the employment increase.

Three policy implications can be drawn based on the empirical findings of this study. First, tax reduction policies can increase more employment in the populated areas, which is helpful for the overall employment but harmful for the development of less-populated areas. Second, social security tax policies can be a policy device for employment boost at the expense of labour income reduction. Such trade-off is important and useful for government during different cyclical phases. Third, firms of different ownership and scales react to social security tax differently, thus, more specific policies can have better outcomes.

This study only uses a sample for the period between 2004 and 2007. This may limit the external validity of the research and the reference value for current policymaking. Moreover, collection entity shift can mainly have short-term effects since firms and local labour market tend to adapt to new institutional environment. Future studies can focus on the long-term effect or exploit recent policy shocks when better data are available.

\section{References}

[1] Anderson, P., and B. Meyer. 1997 "The effects of firm-specifictaxes and government mandates with an application to the u.s. unemployment insurance program" Journal of Public Economics, 65 (8), pp. 119-145.

[2] Anderson, P., and B. Meyer. 2000. "The Effects of The Unemployment Insurance Payroll Tax On Wages, Employment Claims And Denials" Journal of Public Economics, 78 (1-2), pp.81-106.
[3] Angrist, J., and J. Pischke. 2009. Mostly Harmless Econometrics: An Empiricist's Companion. New Jersey: Princeton University Press.

[4] Besley, T., and A. Case. 2000. "Unnatural Experiments? Estimating the Incidence of Endogenous Policies" Economic Journal, 110 (467), pp. F672-F694.

[5] Gruber, J., and M. Lettau. 2004. "How Elastic Is the Firm's Demand For Health Insurance?" Journal of Public Economics, 88 (7-8), pp. 1273-1294.

[6] Kugler, A., \& M. Kugler. 2009. "Labor Market Effects of Payroll Taxes in Developing Countries: Evidence from Colombia" Economic Development and Cultural Change 57 (2), pp. 335-358.

[7] Kugler, A. and M. Kugler and L. Herrera-Prada. 2017. "Do Payroll Tax Breaks Stimulate Formality? Evidence from Colombia's Reform" Economia Journal of The Latin American and Caribbean Economic Association, 0 (1), pp. 3-40.

[8] Li Z. and Wu M. 2011. "Estimating the incidences of the recent pension reform in China: evidence from 100,000 manufacturers". BBVA Research working paper, No. 11/38.

[9] Liu, J. Q. 2010. "Resource, Incentive, and Political Interest: A Longitude Study of China's Social Security Collection System”. China Social Science, 2010 (3).

[10] Nie, H. H, T. Jiang, and R. D. Yang. 2012. "Status and Problems in the Annual Survey of China's Above-Scale Manufacturing Firms Dataset”. World Economy, 2012 (5).

[11] Nielsen, I. and R. Smyth. 2008. "Who bears the burden of employer compliance with social security contributions? Evidence from Chinese firm level data". China Economic Review. 19 (2008), pp. 230-244.

[12] Rosen, H. and T. Gayer. 2021. Public Finance (the Tenth Edition). New York: The McGraw-Hill.

[13] Saez, E., M. Matsaganis and P. Tsakloglou, 2012. "Earnings Determination and Taxes: Evidence From a Cohort-Based Payroll Tax Reform in Greece" The Quarterly Journal of Economics, Oxford University Press, 127 (1), pp. 493-533.

[14] Saez, E., B. Schoefer and D. Seim. 2017. "Payroll Taxes, Firm Behavior, and Rent Sharing: Evidence from a Young Workers' Tax Cut in Sweden". NBER Working Paper, No. 27936.

[15] Summers, L. "Some Simple Economics of Mandated Benefits". American Economic Review, 79: 177-183. 